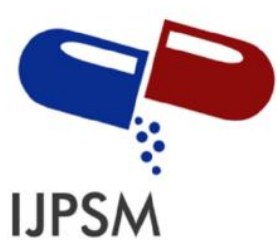

Wilda Marda Ningsih et al, Int. Journal of Pharmaceutical Sciences and Medicine (IJPSM), Vol.6 Issue. 8, August- 2021, pg. 173-181

\title{
REVIEW: THE CHEMICAL COMPOUNDS OF TURKEY BERRY (Solanum torvum Swartz) PLANTS THAT ARE EFFICACIOUS AS MEDICINE
}

\author{
Wilda Marda Ningsih'; ${ }^{1}$ Zulharmita'; ${ }^{1}$ Ridho Asra ${ }^{1}$; Boy Chandra' \\ School of Pharmaceutical Science (STIFARM), Padang \\ Email: boy kimia89@yahoo.com \\ DOI: 10.47760/ijpsm.2021.v06i08.013
}

\begin{abstract}
Indonesia has many plants that can be used as sources of food and medicine, one of them is the turkey berry plant (Solanum torvum Swartz). Turkey berry has many properties for the treatment of various diseases. This is influenced by the content of chemical compounds such as steroids, saponins, flavonoids, alkaloids, and various vitamins that function as antioxidants, cardiovascular and immunomodulators. Morphologically, the turkey berry plants used for treatment are the leaves, fruit, and roots. Therefore, in compiling this article, various sources were gathered such as from ScienceDirect, ResearchGate, Google Scholar, Sci-Hub, CABAbstracts, Elsevier, and other published and trusted journals.
\end{abstract}

Keywords: turkey berry plants; traditional medicine; phytochemicals; pharmacological activity

\section{INTRODUCTION}

Indonesia has many plants that can be used as a source of food and medicine, one of them is the turkey berry (Solanum torvum Swartz). Turkey berry has been widely known as a vegetable whose fruit can be eaten raw and can be used in traditional medicine.[1] Turkey berry is an important species in the field of pharmacology because it has been widely used in traditional Chinese medicine and Ayurveda as well as in several other Asian countries.

Empirically, the leaves can be dried and made into powder and mixed with hot water to treat coughs or colds, the roots can be powdered to relieve pain in broken legs, the dried fruit can be used as a cough suppressant, the leaf extract can be used to relieve fever, and its root extract can be used for the treatment of asthma and liver disease.[2] This plant is characterized by its oval leaves, growing alternately, $10-15 \mathrm{~cm}$ long, 8-10 cm wide. The flowers are white, the fruit is small, green when ripe, the color is yellow, the seeds are many and the flesh is small. The seeds are flat, brown in color, 1.5-2 mm long. It smells 


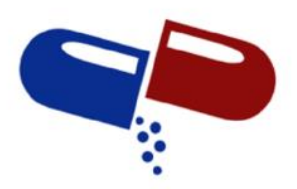

\section{IJPSM}

Wilda Marda Ningsih et al, Int. Journal of Pharmaceutical Sciences and Medicine (IJPSM), Vol.6 Issue. 8, August- 2021, pg. 173-181

ISSN: 2519-9889

Impact Factor: 3.426

like pepper.[3]

This plant has different names in each region, such as rimbang (West Sumatra and Malay), takokak (West Java), and terong cepoka (Central Java). This plant has been used as a traditional medicine in the community, especially in West Sumatra because it is used as an eye medicine. Therefore, this plant can support the lifestyle of today's people who want to consume natural medicines.[4]

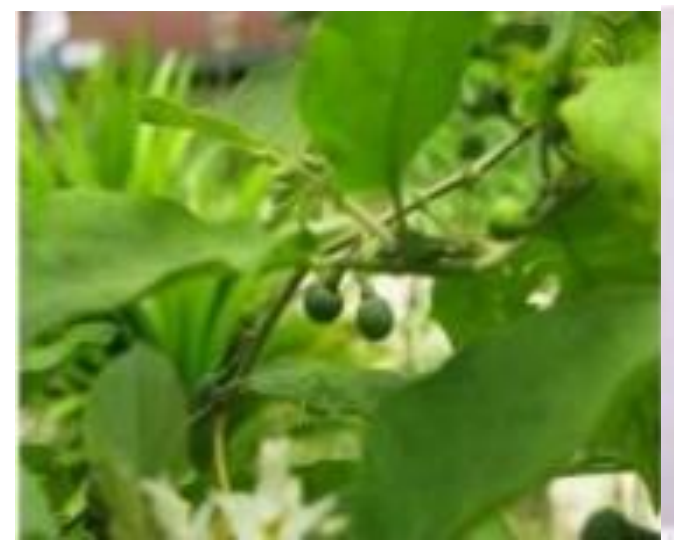

Figure 1. Turkey berry plants [4]

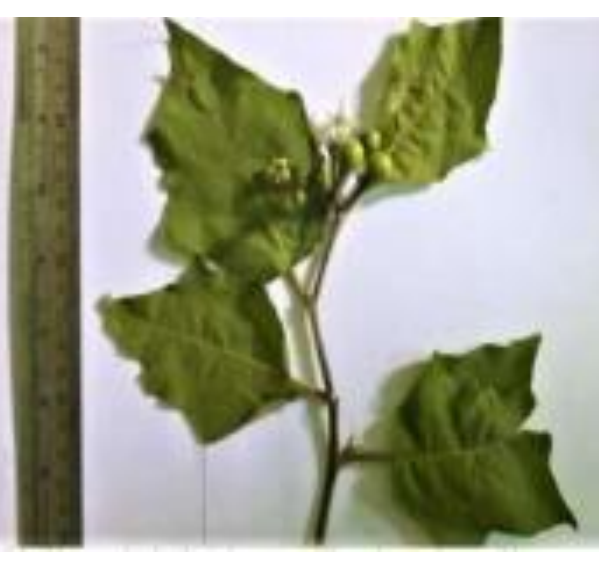

Figure 2. Turkey berry plants [1]

\section{Plant Classification [2]}

Division: Spermatophyta

Subdivision: Angiospermae

Class: Dicotyledoneae

Nation: Solanales

Tribe: Solanaceae

Genus: Solanum

Species: Solanum torvum $S w$. 


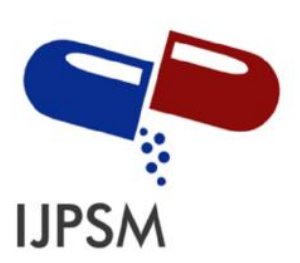

Wilda Marda Ningsih et al, Int. Journal of Pharmaceutical Sciences and Medicine (IJPSM), Vol.6 Issue. 8, August- 2021, pg. 173-181

ISSN: 2519-9889

Impact Factor: 3.426

\section{METHODS AND DATA COLLECTION}

In writing this review article, the method used in the literature study is relevant to the purpose of the review. After evaluating the information on the Internet (using ScienceDirect, ResearchGate, Google Scholar, Sci-Hub, CABAbstracts, Elsevier), it is clear that Solanum torvum Swartz belongs to the Solanacea family. To find the journals, keywords used were as follows:turkey berry plants; traditional medicine; phytochemicals; pharmacological activity.

\section{RESULTS AND DISCUSSION}

\subsection{Benefits of Turkey Berry Plants}

The use of plants as traditional medicine is still used by people in Indonesia, especially in rural areas which are still rich in plant diversity. In addition to being cheap and easy to obtain, traditional medicines derived from plants also have far lower side effects than medicines that contain chemicals. There are still many Indonesian traditional medicines that have not been studied, especially those from plants [5].

Turkey berry plant is one type of plant that is efficacious as a traditional medicinal ingredient and has the potential to be developed as traditional medicine. Turkey berry plant parts used for treatment are the leaves, fruit, and roots, to treat stomach pain and menstruation, stiff or swollen waist, chronic cough, ulcers or sores, palpitations (tachycardia), heart pain, and lowering high blood pressure. The use of these medicinal plants is still done traditionally, namely by boiling or eating raw, for medicinal purposes, plant material is still taken from nature. The plant has been used as a traditional medicine in the community, especially in the West Sumatra area because it is used as an eye medicine [4], therefore, this plant can support the lifestyle of today's people who want to consume medicines made from natural ingredients.

\subsection{Phytochemical Review of Turkey Berry Plants}

Turkey berry plant (Solanum torvum) thrives in the territory of Indonesia as a wild plant and its cultivation is still limited. The potential of Turkey berry as herbal medicine 


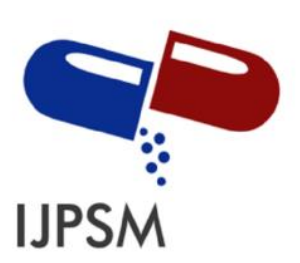

Wilda Marda Ningsih et al, Int. Journal of Pharmaceutical Sciences and Medicine (IJPSM), Vol.6 Issue. 8, August- 2021, pg. 173-181

ISSN: 2519-9889

Impact Factor: 3.426

abroad is quite a lot, while in Indonesia its use is limited. According to Jaiswal (2018), Turkey berry plants (Solanum torvum) contain steroid glycosides, saponins, flavonoids, vitamin B groups, vitamin C, iron salts, steroidal alkaloids as antioxidants, cardiovascular and immunomodulators. This is supported by the opinion of Mohan et al. (2010), that Solanum torvum fruit contains flavonoids, alkaloids, tannins, saponins, which function as antioxidants.[6] The presence of methyl caffeine compounds in turkey berry(Solanum torvum) functions as an anti-cancer.[7]

\subsection{Pharmacological Activities}

\section{Anticancer}

Cancer is one of the leading causes of death in the world. Cancer treatment which is very complicated and high-cost encourages people to look for alternative treatments using medicinal plants. Some medicinal plants that are empirically claimed to have anticancer properties are Turkey berry(Solanum torvum).[8] Several new anticancer compoundswhich were later developed were as follows: camptothecin from Camptotheca acuminate and phodopilotoxin (Podophyllum peltatum), including a number of semisynthetic compounds and their derivatives, namely topotecan, irridotekan, docetaxel, cabazitaxel, etoposide, and teniposide.[9] Panigrahi et al. (2014) stated that the ethanolic extract of turkey berryfruit (Solanum torvum) has a strong cytotoxic effect on the growth of Ehrlich's Ascites Carcinoma (EAC) cells. Turkey berry fruit belongs to the Solanaceae family which contains active compounds including steroidal sapogenins which have various pharmacological activities. In vitro cytotoxicity results revealed the anticancer potential of the ethanolic extract of Solanum torvum fruit. Extract concentrations ranging from $50 \mu \mathrm{g} / \mathrm{ml}$ to $1000 \mu \mathrm{g} / \mathrm{ml}$, were tested for $\%$ cytotoxicity, and \% cytotoxicity obtained respectively $7.09 \%$ to $85.79 \%$. This suggests a dose-dependent cytotoxic effect.[10]

Among the common anticancer agents are alkaloids, flavonoids, and phenolic compounds. Phenolic compounds have been used as antioxidants and anti-inflammatory agents. The plant extracts showed the presence of many phenolic compounds from which the compounds having the maximum percentage of peak area were identified using GCMS. They are incorporated into the anti-protein apoptotic BCL2. The docking results show 


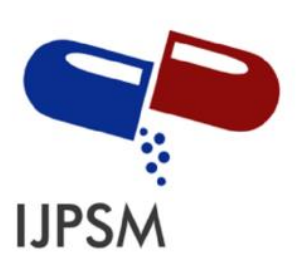

Wilda Marda Ningsih et al, Int. Journal of Pharmaceutical Sciences and Medicine (IJPSM), Vol.6 Issue. 8, August- 2021, pg. 173-181

ISSN: 2519-9889

Impact Factor: 3.426

the binding energy of each compound with BCL2 protein. It is understood that the Solasodine compound with the lowest binding energy $(-6.16 \mathrm{kcal} / \mathrm{mol})$ is considered the most suitable as a protein-ligand complex. This is due to the lowest amount of energy required by Solasodine to bind to the BCL2 protein receptor and cause apoptosis, thereby successfully killing the EAC cell line. So from this research, it is proven that Solanum torvum extract can be developed as a powerful anticancer drug.[10]

\section{Antioxidants}

To analyze the antioxidant activity, a test was carried out by the DPPH method using 2,2 diphenyl-1-picrylhydrazyl (DPPH) with a concentration of $0.1 \mathrm{mM}$, Blank as a control using ethanol as a sample substitute.[6] Antioxidants are substances that inhibit or prevent cell damage due to free radical oxidation. Fruits derived from plants that are included in the Solanum Family have potential as antioxidants, but the antioxidant activity in the leaves is not known. Antioxidant activity parameters were measured by the value of Inhibitor Consentration $\left(\mathrm{IC}_{5} 0\right)$. Identification of phytochemical content and qualitative antioxidant activity test was done using thin-layer chromatography (TLC). Antioxidant activity was quantitatively tested by UV-Vis spectrophotometry at a wavelength of 515 $\mathrm{nm}$ with a ratio of vitamin $\mathrm{C}$. The results showed that Solanum Family leaves contain flavonoids, saponins, and polyphenols. $\mathrm{IC}_{5}$ o value of Turkey berry leaves was $107.42 \pm$ $0.43 \mathrm{ppm}$ (moderate antioxidant activity), injection of vitamin $\mathrm{C}$ as a positive control with $\mathrm{IC}_{5} 0$ value of $2.89 \pm 0.20 \mathrm{ppm}$ (very strong antioxidant activity). The results showed that the ethanol extract of Solanum Family leaves produced antioxidant activity. [11]

\section{Anti-platelet}

Hemostatic properties of turkey berry plants provide an anti-platelet aggregation effect (Henty, 1973). The anti-platelet aggregation activity of an aqueous extract of herbaceous plants (AES) was evaluated in vitro on platelet aggregation initiated by thrombin and ADP.[12] The results showed that the anti-activity platelet aggregation was concentration-dependent. At $2 \mathrm{mg} / \mathrm{ml}$, AES reduced the amplitude of the aggregation signal induced by thrombin from $9.27 \mathrm{~cm}$ to $4.03 \mathrm{~cm}$, representing a $55.27 \%$ inhibition. 


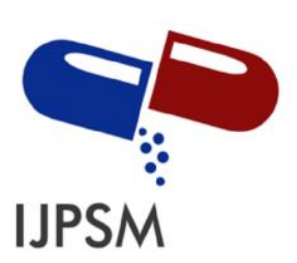

Wilda Marda Ningsih et al, Int. Journal of Pharmaceutical Sciences and Medicine (IJPSM), Vol.6 Issue. 8, August- 2021, pg. 173-181

ISSN: 2519-9889

Impact Factor: 3.426

This effect was significantly higher than the lower concentrations of 0.5 and $1 \mathrm{mg} / \mathrm{ml}$. Similarly, AES also exerts a significant concentration-dependent inhibitory effect on ADPinduced aggregation. The effect in terms of percentage inhibition was $31.63 \%, 47.07 \%$ and $56.40 \%$ at concentrations of $0.5,1$ and $2 \mathrm{mg} / \mathrm{ml}$ respectively.[20]

\section{Anti-Inflammatory and Analgesic}

Medicinal plants are one of the important medicinal species used as an analgesic and anti-inflammatory agents in various traditional medicine systems.[16] Analgesic and anti-inflammatory activity of leaf plants were evaluated for chemical and mechanical stimulation. Results showed stomachwrithing and paw edema induced in rats using $1 \%$ acetic acid $(1 \mathrm{ml} / 100 \mathrm{~g}$ body weight $)$ and $0.05 \mathrm{ml}$ solution of $1 \%$ sterile carrageenan in saline. For the treatment of $1 \%$ acetic acid $(1 \mathrm{ml} / 100 \mathrm{~g}$ body weight) caused the stomach to swell, an aqueous extract of the turkey berry plant was used together with three other painkillers. The aqueous leaf extract of the herbaceous plant significantly inhibits pain. Foot edema caused by $0.05 \mathrm{ml}$ sterile $1 \%$ carrageenan solution was treated with indomethacin $(10 \mathrm{mg} / \mathrm{kg})$, turkey berry $(300 \mathrm{mg} / \mathrm{kg})$ and turkey berry $(600 \mathrm{mg} / \mathrm{kg})$. The extracts of turkey berry $(300 \mathrm{mg} / \mathrm{kg})$ and turkey berry $(600 \mathrm{mg} / \mathrm{kg})$ significantly inhibited leg edema although a low dose of $300 \mathrm{mg} / \mathrm{kg}$ worked more effectively in a shorter period of time compared to a high dose of $600 \mathrm{mg} / \mathrm{kg}[10]$

\section{Diabetes Mellitus}

Diabetes Mellitus is a chronic metabolic disorder characterized by hyperglycemia involving abnormalities in both insulin secretion and action on peripheral tissues.[17] The herbaceous plant (Solanaceae) is a very small shrub widely distributed in South India, Malaya, China, the Philippines, and Tropical America. Its edible fruit, commonly available in the market, is used as a vegetable and is considered an important ingredient in the diet of the people of South India. Pharmacological studies on this fruit show the antidiabetic properties of the fruit.[18] Diabetes mellitus (DM) is characterized by a decrease in secretion or insulin resistance, resulting in the metabolism of glucose in the blood is not running properly so that blood glucose levels are higher than normal (hyperglycemia) [19 


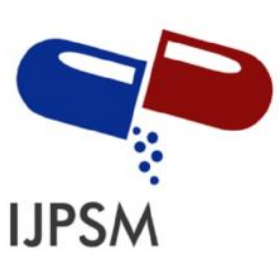

Wilda Marda Ningsih et al, Int. Journal of Pharmaceutical Sciences and Medicine (IJPSM), Vol.6 Issue. 8, August- 2021, pg. 173-181

ISSN: 2519-9889

Impact Factor: 3.426

$\&$ 17]

The fruits of Solanum torvum are widely used in the system of traditional medicine to treat diabetes mellitus. Oral administration of methyl caffeate $(10,20$, and $40 \mathrm{mg} / \mathrm{kg})$ produced from turkey berry plants for 28 days in experimental rats has been reported by Gandhi et al. (2011). Methyl caffeate at a dose of $40 \mathrm{mg} / \mathrm{kg}$ significantly prevented an increase in blood glucose after administration of glucose for 60 minutes in a group of hyperglycemic rats. Methyl caffeate administered to mice showed upregulation of GLUT4 and regeneration of cells in the pancreas.[18] GLUT4 is a protein encoded by the GLUT4 gene found in skeletal muscle. Experiments were carried out on animals fasted overnight; Diabetes was induced by intraperitoneal injection of streptozotocin dissolved in $0.1 \mathrm{M}$ cold

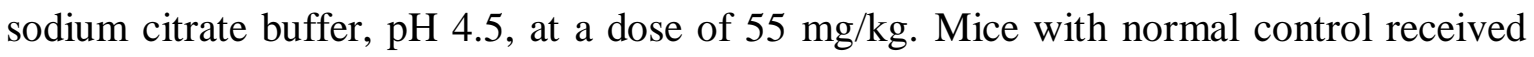
only the same volume of citrate buffer. Food was given to them 2 hours after the injection. After 1 week, mice with severe diabetes who had hyperglycemia (fasting blood glucose range above $16.65 \mathrm{mmol} / \mathrm{l}$ ) were considered diabetic.

\section{CONCLUSION}

Based on the studies conducted, turkey berry plants (Solanum torvum Swartz) have bioactivity as chemical components, namely alkaloids, flavonoids, and phenolic compounds. Phenolic compounds have been used as antioxidants and anti-inflammatory. Anti-inflammatory activity was measured by testing for edema in the feet of rats induced by carrageenan and treated with indomethacin, while the antioxidant activity of turkey berry fruit contains flavonoids, alkaloids, tannins, and saponins that can inhibit or prevent cell damage due to free radical oxidation, however, antioxidant activity is not known in the leaves of turkey berry. Therefore, this shows that the turkey berry plant has the potential to be developed as a source of various pharmacological activities. 


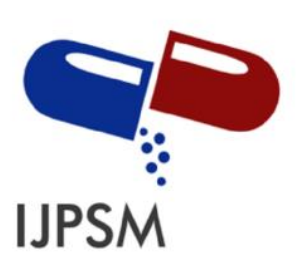

Wilda Marda Ningsih et al, Int. Journal of Pharmaceutical Sciences and Medicine (IJPSM), Vol.6 Issue. 8, August- 2021, pg. 173-181

ISSN: 2519-9889

Impact Factor: 3.426

\section{REFERENCES}

[1]. Alfarabi M, Widyadhari G. TOXICITY TEST AND PHYTOCHEMICAL IDENTIFICATION OF RIMBANG (Solanum torvum Swartz) EXTRACT. AL KAUNYAH: Journal of Biology. 2018 Mar 16:11(2):109-15.

[2]. Yousaf Z, Wang Y, Baydoun E. Phytochemistry and pharmacological studies on Solanum torvum Swartz. Journal of Applied Pharmaceutical Science. 2013 Apr;3(4):152-60.

[3]. Helilusiatiningsih N. PROCESSING OF POKAK EGGPLANT (Solanum torvum) TO BECOME HERBAL TEA AS A FUNCTIONAL BEVERAGE. THE BUANA SAINS. 2021 Feb 1;20(2):139-48.

[4]. Sirait N. Eggplant Cepoka (Solanum torvum) Herbs that are efficacious as medicine. Report on Research and Development of Industrial Plants. 2009;15(1):11-3.

[5]. Lely, N. (2016). Antimicrobial activity test of turkey berry leaf extract (Solanum torvum Swartz) against Staphylococcus aureus, Escherichia coli and fungiCandida albicans. Jurnal ilmiah bakti farmasi, 1(2): 55-58

[6]. Helilusiatiningsih N, Soenyoto ES. Analysis of Antioxidant Bioactive Compounds and Nutrientson Pokak Eggplant (Solanum Torvum) Fruit as a Functional Foodstuff. Buana Sains. 2020 Jun 30;20(1):7-19.

[7]. Balachandran C, Emi N, Arun Y, Yamamoto Y, Ahilan B, Sangeetha B, Duraipandiyan $\mathrm{V}$, Inaguma $\mathrm{Y}$, Okamoto A, Ignacimuthu S, Al-Dhabi NA. In vitroanticancer activity of methyl caffeate isolated from Solanum torvum Swartz. fruit. Chemico-biological interactions. 2015 Dec 5;242:81-90.

[8]. Widiyastuti Y, Sholikhah IY, Haryanti S. Cytotoxic effect of jamu formula of soursopleaves, takokak fruits, and bidara upas bulb against breast cancer cell line MCF-7. Jurnal Kefarmasian Indonesia. 2019;9(2):140-9.

[9]. Khazir J, Riley DL, Pilcher LA, De-Maayer P, Mir BA. Anticancer agents from $\begin{array}{llll}\text { diversenatural sources. Natural product communications. } 2014 & \end{array}$ Nov;9(11):1934578X1400901130.

[10].Panigrahi S, Muthuraman MS, Natesan RA, Pemiah BR. Anticancer activity ofethanolic extract of Solanum torvum sw. International Journal of Pharmacy and Pharmaceutical Sciences. 2014;6(1):93-8.

[11].Artanti AN, Lisnasari R. Antioxidant activity test of ethanol extract of solanum family leavesusing the DPPH free radical reduction method. Journal of Pharmaceutical Science and Clinical Research. 2018;2:62-9.

[12].Nguelefack TB, Feumebo CB, Ateufack G, Watcho P, Tatsimo S, Atsamo AD, Tane $\mathrm{P}$, Kamanyi A. Anti-ulcerogenic properties of the aqueous and methanol extracts fromthe leaves of Solanum torvum Swartz (Solanaceae) in rats. Journal ofethnopharmacology. 2008 Sep 2;119(1): 135-40.

[13]. Bari MA, Islam W, Khan AR, Mandal A. Antibacterial and antifungal activity of Solanum torvum (Solanaceae). Int J Agric Biol. 2010 May 1;12(3):386-90.

[14].Loganayaki N, Siddhuraju P, Manian S. Antioxidant activity of two traditional Indianvegetables: Solanum nigrum L. and Solanum torvum L. Food Science and Biotechnology. 2010 Feb 1;19(1):121-7

[15].Agrawal AD, Bajpei PS, Patil AA, Bavaskar SR. Solanum torvum Sw.-a 


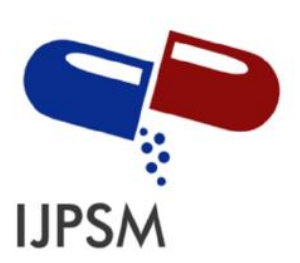

Wilda Marda Ningsih et al, Int. Journal of Pharmaceutical Sciences and Medicine (IJPSM), Vol.6 Issue. 8, August- 2021, pg. 173-181

ISSN: 2519-9889

Impact Factor: 3.426

phytopharmacological review. Der pharmacia lettre. 2010;2(4):403-7.

[16].NDEBIA, EJ; KAMGANG, R.; NKEH-CHUNGAGANYE, BN Analgesic and antiinflammatory properties of aqueous extract from leaves of Solanum torvum (Solanaceae). African Journal of Traditional, Complementary and Alternative Medicines, 2007, 4.2: 240-244.

[17].Tian, XJ, Wang, A., Mehendale, S., 2003. Antidiabetic effect of Gymnema Yunnanese extract. Pharmacol. res. 47, 323-329.

[18].GANDHI, Gopalsamy Rajiv, et al. Antihyperglycemic activity and antidiabetic effect of methyl caffeate isolated from Solanum torvum Swartz. fruit in streptozotocininduced diabetic rats. European journal of pharmacology, 2011, 670.2-3: 623-631.

[19].Munim, A. \& Hanani, E. (2011). Basic Physiotherapy. People's Diane. Jakarta. viii + $356 \mathrm{pp}$.

[20].NGUELEFACK, Télesphore Benot, et al. Cardiovascular and anti-platelet aggregation activities of extracts from Solanum torvum (Solanaceae) fruits in rat. Journal of Complementary and Integrative Medicine, 2008, 5.1. 